\section{Improving our minds}

Mary Warnock

Education Without Impact: How Our Universities Fail the Young. By George $\mathrm{H}$. Douglas. Birch Lane: 1992. Pp. 223. \$19.95.

THERE are two main threads in George H. Douglas's highly critical analysis of universities in the United States. The first is that these universities are dominated by science, the second that, in his words, "Americans have gravitated toward the idea that the university is like a giant department store ... a place where people come to shop for things."

The domination of the natural sciences has led, in Douglas's view, to a corruption of the humanities. He claims that because the sciences have inevitably become increasingly specialized, and bccause there has thus grown up a series of specialist languages embodying concepts barely intelligible to the general public, professionals in the humanities have felt that, to retain their respectability, they must follow the same path. The studies of literature, philosophy, history and languages have all become pseudoscientific, no more accessible to the lay person than science itself.

Especially in the case of literature, Douglas, himself a professor of English, argues that theories of criticism have been developed over the past 40 years or so that have become more important within university departments than the literature they were originally supposed to illuminate. (No one familiar with the English faculty in the University of Cambridge would be much inclined to dispute this.) And just as scientists are concerned above all with research, and their interest, if any, in teaching is directed towards producing new researchers, so in the humanities research has taken precedence over teaching, the only worthwhile teaching being of those pupils who may themselves take up research. The idea of passing on a civilized and civilizing tradition has disappeared. The Germanic concept of the learned doctorate, the scholarly DPhil, is blamed for this degeneration as much as the rise of science itself. But once the DPhil is firmly in place, it is hard to eliminate, because it becomes a necessary step to advancement. Such corruption of the humanities has been a creeping phenomenon, and has, according to Douglas, been visible all through this century.

The development of the university as a supcrmarket is of much later growth, although the two phenomena are not unconnected. According to Douglas, by the 1960)s, undergraduates had become not only numerous, but also too patently neglected by their professors, overly accustomed to bcing fobbed off with huge impersonal lectures and to having their examinations graded by graduate students scarcely older than themselves. So it was inevitable that they should decide to take matters into their own hands and demand to change the university curriculum to make it easier and more user-friendly. They also began to demand, as customers will, better value for money; and this meant higher grades. So while the test grades of school-leavers became lower, the grades they were given in their university examinations grew ever higher. They had come to think of undergraduate education as simply a stage to be got through before going on to the graduate or professional stage; and to ease their passage they needed good grades.

Everyone reading this threnody will find a good deal in it that is recognizable; it is a threnody, moreover, that has been sung beforc. It is inevitable that readers should compare what has happened in the United States with what has happened, or is about to happen, in other countries. The comparison with UK universities in particular is absolutely irresistible. For Douglas is an Anglophile, at least as far as university education goes. Moreover, he is nothing if not romantic. He draws a picture of the community of scholars in the colleges of Oxford and Cambridge fit to wring tears from a stone. He is perhaps unaware that the last but one UK Secretary of State for Education, Kenneth Baker, advised five years ago that British universities should learn to model themselves on the American pattern. Since then the number of universities has vastly increased, and the overall number of undergraduate students is rising, but with no more resources for teaching.

Douglas accepts, perhaps too readily, that the universities of Oxford and Cambridge are elitist institutions, and that their style of undergraduate teaching depends on relatively small numbers; but he takes a tough line about this. Elitism is, in his eyes, a necessary good for universities. Nevertheless he is insistent that professional academics must not get out of touch with society at large, their contacts being their own pupils (whom they are to meet in the idyllic setting of the college) and their publications. They must be proud to write for popular, at least readable periodicals, and generally make use of the media to disseminate their ideas.

This is sensible advice, as far as it goes. But there are two major issues that today preoccupy everyone concerned with higher education, and on which Douglas is completely silent. How is the idea of a university to be reconciled with the idea of near-universal tertiary education? And how are universities to be funded? The absence of any discussion of these issues gives his book a curiously old-fashioned flavour. It scems to me

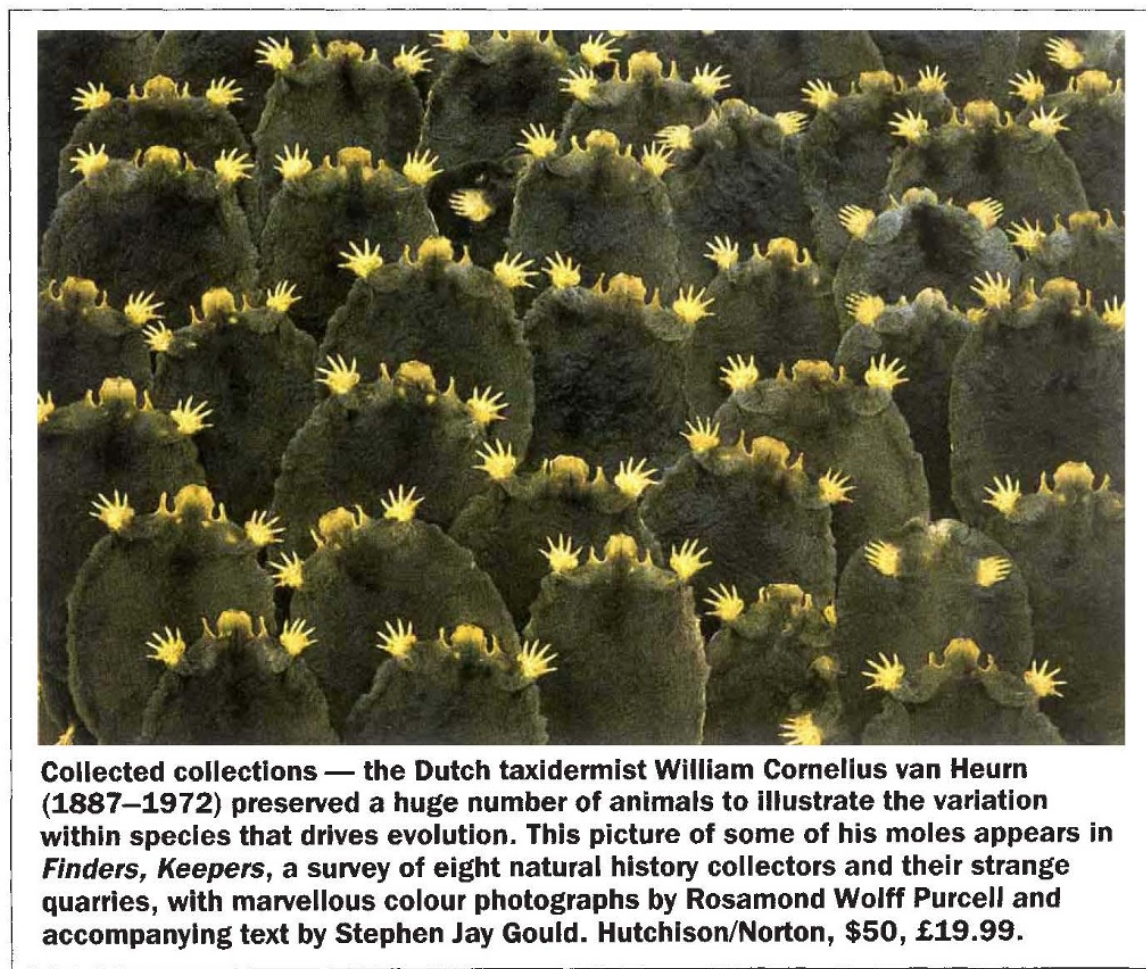

NATURE · VOL 360 - 26 NOVEMBER 1992 
that the logic of his position is that only a handful of students will benefit from what he regards as true university education, whether in the sciences or the humanities. Only a few can be taught face-to-face by tutors who know them and are prepared to discuss their work with them in detail. Others will need technical expertise, or perhaps preliminary training, before going on to law school, business school or medical school, or into employment. This would entail a distinction, acknowledged or otherwise, between true universities, essentially suitable for only a minority, and training colleges, rather like the original distinction between universities and polytechnics (a distinction which is now defunct in the United Kingdom). It would also entail a distinction between academically indulgent institutions, with high and general educational aims, and functional institutions with precise practical goals, expected to give clear value for money. The likelihood is that public funding would be available only for the latter. But perhaps Douglas would not mind. Rightly or wrongly, the United Kingdom has just turned its back on this kind of dichotomy. For the time being, all universities are supposed to be equal.

There is, however, one further question, in my view the most fundamental of all, to which Douglas's answer is unclear. What is the ideal relation between teaching and research? He blames professors for taking their research too seriously, and palming off their teaching on their juniors. But he does not suggest any means to reverse this practice. In the United Kingdom it begins to look increasingly as if research, especially scientific research, will come to be based in a few selected universities, undergraduate teaching being the main responsibility of the rest. Graduate students will presumably find their way to the research universities, to be supervised by those actively engaged in research. Undergraduates will thus be taught by professional teachers, as they were at school The teaching institutions will become, in effect, tertiary schools ('schools with ash-trays', as someone has called them). Professors will no longer incur blame for not caring about undergraduates, because they will have no undergraduates to care about in their research-orientated lives. Things may well come to this. When they do, I shall almost feel inclined to join Douglas in his nostalgia for the old days at Oxford and Cambridge, though I feel sure, as he apparently does not, that those days are over (and in any case, they were ncver perhaps quite so glorious as he assumes).

Baroness Warnock is at Brick House, Axford, Wiltshire SN8 2EX, UK.

\section{Unreasonable ambition}

Ernest Gellner

Irrationality: The Enemy Within. By Stuart Sutherland. Constable: 1992. Pp. 357. £14.95.

STUART Sutherland is a rationalist. So, as it happens, am I. So you might expect me to acclaim an author who expresses views, attitudes and values very much akin to my own, and who does it with verve, eloquence, coherence and in good, clear prose. In fact, however, this book leaves me feeling very uneasy. Why do I not salute an intellectual friend and ally? Why the reservations about this survey of modern follies and their causes?

Let us go straight to the heart of the matter. Sutherland is not merely a rationalist, he is also a psychologist. Moreover, although he is clearly a highly intelligent and able member of the species, the trouble is that he is also, in his basic attitude, a fairly typical one. Scratch an anthropologist and you'll find a philosopher, and sometimes even one with a sense of history; sociologists sometimes have the same merits; but psychologists, seldom. Scratch a psychologist, and you'll generally find a man eager to flee the humanities and act up to a certain conventional model of a scientist. I'm not sure this is true of all the other books of Sutherland's, notably Breakdown, which was highly personal, but it is true of this one.

It isn't that I in any way disapprove of Sutherland's aspiration to expose irrational behaviour: my worries spring rather from the fear that he has greatly underestimated the difficulties of the task. The underlying assumption of this book is that its subject's opposite, reason, is easy to identify. It is, as Spinoza said about truth, the touchstone both of itself and of its error. It is readily available, luminous and obvious, and so is unreason. I do not know whether Sutherland would plead guilty to this accusation when so spelt out, but its influence on his argument, at any rate in this book, is evident from the terrible clarity of the battle lines: he can spot unreason so very clearly; he knows his enemy, because he also knows, with disturbing and facile confidence, how to identify our position, rationality. Neither poses any problems for him, really.

His conception of rational thought and conduct owes a great deal to basic statistical ideas and to the economists' conception of sensible market behaviour. Rational man is careful in his handling of evidence, avoids well-known fallacies and rigidity and sheep-like behaviour, and his lucidity in making inferences from the database at his disposal is matched by his clarity about his aims and the assessment of what will serve them best. Clearly he is an enlightened individualist who will not follow a multitude to commit folly.

An admirable ideal, and I share Sutherland's admiration. But the book contains no serious discussion of the social and historical preconditions of the emergence of this strange animal, or any sense of his untypicality, in wider historical context. The index does not contain the name of Max Weber or of any of those who have been puzzled by the emergence of rationality, not even that of James Frazer (whose views on this topic were not so far from Sutherland's, though he had far more sense of my feeling for the poetry of unreason). The disaggregation of the world into isolable elements that can then be subjected to statistically proper interpretations, the disaggregation of conduct into isolable and freely chosen aims permitting costbenefit calculations - all this is the achievement of one type of society, it is not inherent in the human condition. It is not part of our birthright. Like believers in a Revelation who condemn to hellfire those who preceded it and had no access to it, Sutherland's ideal implicitly condemns much of mankind to servitude to unreason. Perhaps he would say that there is no point in deploring that which is beyond remedy, but the problem is not perceived.

But the situation isn't all that simple even among us, where reason is an important though not exclusive norm. Another obvious name missing from the index is that of Thomas Kuhn. Without accepting everything in the work of this philosopher, it is difficult to dispute his main claim about the nature of science: namely that, except in the course of major revolutions, science works and can only work through a kind of socially, culturally induced dogmatism, a prejudgement of major and objectively contentious issues, the imposition of a shared paradigm. If this is true among scientists working in a milieu disconnected from their social identity and its pressures, and in the main imbued by an individualistic-rationalistic spirit, how much truer it must be of ordinary life and its strategies, which are Sutherland's concern! To put it another way: the data at our disposal do not uniquely dictate what we should think about our environment. Far from it. Theories, as the phrase goes, are under-determined by facts. There is simply far too much slack between evidence and conclusion: unreason, sheep-like thinking, rigidity, call it what you will, must take up this slack.

To say all this is not to ask Sutherland 